\title{
Construction waste management policies and their effectiveness in Hong Kong:
}

\author{
A longitudinal review \\ Weisheng $\mathrm{Lu}^{1}$ and Vivian W. Y. Tam ${ }^{2} *$ \\ ${ }^{1}$ Assistant Professor, Department of Real Estate and Construction, Faculty of Architecture, \\ The University of Hong Kong, Pokfulam, Hong Kong. \\ ${ }^{2 *}$ Corresponding author, School of Computing, Engineering and Mathematics, University of \\ Western Sydney, Locked Bag 1797, Penrith, NSW 2751, Australia. Email: \\ vivianwytam@gmail.com, \\ Tel: (61)2-4736-0105, Fax: (61)2-4736-0833.
}

\begin{abstract}
Solid waste arisen from construction activities is grave concern in many economies. Given its negative impacts to the natural environment as a public good, construction waste is often heavily regulated by authorities. Hong Kong is no exception to this; over the past decades, a series of construction waste management (CWM) policies including regulations, codes, and initiatives have been introduced by the Government and her executive arms. It comes to an opportune time to retrospectively examine the effectiveness of these policies with a view to providing insights for further improvement. The aim of this paper is thus to examine CWM policies and their effectiveness in Hong Kong by conducting a longitudinal study. The evaluation of the policy effectiveness is derived by triangulating empirical data collected from various sources including Hong Kong Census and Statistics Department, Civil Engineering and Development Department, Environment Protection Department, and Hong Kong Construction Association with the qualitative data gleaned from interviews and case studies in construction sites, waste sorting facilities, and landfills. It is found that Hong Kong is actively trying new CWM policies based on latest waste management philosophies available (e.g. reduce, reuse, and recycle principle, and polluter pays principle). These policies have formed an interlocking, and relatively effective policy framework for CWM in Hong Kong. However, new initiatives are desired if aiming to change the gloomy situation since 2006 when the construction waste disposal charging scheme was effectively implemented. This research provides insightful understanding of CWM policies and their effectiveness, which is often concerned policies makers, researchers, and the like.
\end{abstract}

Keywords: construction waste; waste management; public policy; Hong Kong 


\section{Introduction}

With the increasing embracement of sustainable development as a new value [1], the construction industry has started to realize its adverse impacts on the environment [2]. Construction by nature is not an environment-friendly activity. Researchers have provided comprehensive reviews of the negative impacts caused by construction activities, which mainly include land deterioration, resource depletion, waste generation, and various forms of pollution [3-8].

Amongst the many negative impacts, construction waste often constitutes a prodigious portion of the total municipal solid waste in contributing to the environment degradation [912]. Owing to its non-combustible nature, construction waste normally ends at landfills. In the United Kingdom, for example, more than $50 \%$ of waste deposited in a typical landfill come from construction [13]; while about 70 million tons of waste are arisen from construction and demolition activities [14]. In Australia, about 14 million tons of waste have been put into landfill each year, and about $44 \%$ of waste are attributed to the construction industry $[15,16]$. In the United States of America, around $29 \%$ of solid-waste are from construction [17]. Waste in landfill leads to extensive amounts of air, water and soil pollution due to the production of $\mathrm{CO}_{2}$ and methane from anaerobic degradation of the waste.

There are two generic approaches for dealing with construction waste. From a technical point of view, environmental engineers investigate how "hard” technologies can help reduce, reuse, or recycle construction waste, i.e. through introduction of prefabrication, using metal formwork, and using recycled aggregate for different concrete applications. By appreciating that construction waste is also a social issue, "soft" economical or managerial measures have gained momentum. Particularly, governments around the world have endeavoured to enact public policies for regulating construction activities with a view to reducing its negative impacts to the natural environment as a typical public good. Here, public policy is an inclusive term which may be comprised of ordinances, regulations, codes of practice, and initiatives introduced by government or its executive arms. This echoes with Kilpatrick who defines public policy as "a system of laws, regulatory measures, courses of action, and funding priorities concerning a given topic promulgated by a governmental entity or its representatives” [18]. 
Hong Kong is no difference. In Hong Kong, the latest figures on municipal solid waste ending up at landfills reached 13,458 tons per day (tpd) in 2011, of which about 25\% is construction waste [19]. In addition to the environmental impacts, construction waste also brings tremendous pressure to the valuable landfill space in this compact city. Statistics showed that construction waste cost the Government more than HK\$200 million annually for landfill disposal and took up landfill space at a rate of about $3,500 \mathrm{~m}^{3}$ per day $[20,21]$. The Hong Kong Environment Protection Department (EPD) predicted that with an estimated 24\% annual increase in construction waste to be disposed of, the landfill facilities will be full in the next 10 years [22]. There is an acute need to manage the waste in Hong Kong, and consequently, to reduce its negative impacts on the environment and alleviate the pressure on valuable landfills. A series of CWM policies including regulations, codes, and initiatives have been introduced by the Government and her executive arms. Nevertheless, whether the policies are effective is an answered question concerned by policy makers, practitioners and scholars.

The aim of this study is to examine the effectiveness of CWM policies enacted in Hong Kong over the past decades. The rest of the paper is organized as follows. Methodology is introduced in Section 2. A policy framework for and a "roadmap" of CWM in Hong Kong are introduced in Sections 3 and 4 respectively. In-depth interpretations of the policies are analyzed and discussed in Section 5 by triangulating the empirical data with the qualitative data collected from interviews and case studies. Conclusion follows in Section 6. This research not only illustrates how the CWM policies evolve into a policy system in Hong Kong, but also sheds light on their effectiveness. Although the study is conducted in Hong Kong, it is expected that the findings could also provide insights to other jurisdictions, which aspire to appreciate the importance of construction while reducing its negative impacts on the natural environment.

\section{Methods}

In view of the designated research aim, this research adopts a longitudinal study as the core of the methodology. A longitudinal study is a correlational research study that involves repeated observations of the same variables over long periods of time [23]. It has several advantages, e.g. the changes in variables can be captured and the relationships among these changes can be better analyzed, while the disadvantage is that it takes a lot of time and is very 
expensive. In this study, EPD has a themed website to introduce CWM in Hong Kong. It also periodically releases construction waste statistics of the past few years through an annual report entitled “Monitoring of Solid Waste in Hong Kong” [24]. The availability of construction waste data is amenable for this longitudinal review.

As the first step, desktop studies have been conducted to outline the policies in relation to waste management in general and CWM specifically. The policies are then organized in a graphic presentation as a policy framework (Fig. 1) to give readers, who might not be acquainted with Hong Kong, a full picture of how CWM is regulated in this economy. This framework will also serve as a guideline, alongside which the effectiveness of the policies can be better examined. However, it is open to lengthy theoretical debates as to what is meant by policy effectiveness. Apart from direct impacts, a CWM policy may have spillover effects [25]. In addition, “effectiveness” means different things to different stakeholders in CWM. Bearing these debates in mind, this study uses the volumes of waste generated and landfilled as the criteria to measure policy effectiveness, given that they are promulgated to minimise waste, and in turn, to slow down the depletion of the limited landfills in Hong Kong. Construction waste is easy to see, as well as relatively easy to measure [2, 26]. Empirical data relating to the volumes of waste generated and landfilled was collected from various sources including Monitoring of Solid Waste in Hong Kong, the Census and Statistics Department (CSD), and Civil Engineering and Development Department (CEDD).

The above empirical data was then preliminary processed by linking it to the policy framework as shown in Fig. 1. Some interesting correlations have been observed and analyzed against current literature. Other in-depth interpretations of the policies including their rationales, theoretical grounds, interconnections, and effectiveness were obtained through conducting interviews and case studies in governmental departments, off-site construction waste sorting facilities, landfills, and construction sites. For example, an interview with the former Secretary for the Environment, Transport and Works of the Hong Kong SAR was conducted, which helps understand the background of the policies. From January to December 2012, members in the research team have been intensively involved in case studies in an off-site construction waste sorting facilities located at the Tuen Mun Area 38 in Hong Kong, a strategic landfill located in Tseung Kwan O, and 12 construction sites in the territory. The qualitative data collected was then triangulated with the empirical data to gain insights into the effectiveness of the CWM policies in Hong Kong. 


\section{A policy framework for construction waste management in Hong Kong}

Over the past decades, a series of policies have been enacted by the Government. It has formed a CWM policy framework (see Figure 1).

\section{$<$ Figure $1>$}

\section{- P1: Waste Disposal Ordinance}

In 1980, the Waste Disposal Ordinance was enacted to provide a comprehensive framework for managing waste from the point of arising to the point of final disposal. The intention was that waste should be disposed of in an environmentally acceptable manner.

- P2: 10-year Plan

In 1989, a comprehensive 10-year plan was launched to reduce construction waste and other pollution problems.

\section{- P3: Green Manager Scheme}

In 1994, a Green Manager Scheme was set up by the Government to appoint respective Green Managers in all government branches and departments to oversee green house-keeping matters in their offices, for example, measures to minimize water use and save energy.

\section{- P4: Waste Disposal Regulations}

In 1995, the Waste Disposal (Charges for Disposal of Chemical Waste) Regulation and the Waste Disposal (Charges for Disposal of Waste) Regulation were introduced to require payment of charges for disposal of chemical waste and solid waste at landfills.

\section{- P5: Waste Disposal (Designated Waste Disposal Facility) Regulation}

In 1996, the Waste Disposal (Designated Waste Disposal Facility) Regulation was introduced to provide for the maintenance of orderly conduct within sites used for waste disposal activities, measures to counteract the evasion of charges payable in connection with the provision of waste disposal services at such sites, and proof of matters in proceedings before a court in relation to the provision of waste disposal activities at such sites.

\section{- P6: Waste Reduction Framework Plan}

In 1998, a Waste Reduction Framework Plan was initiated to target municipal solid waste reduction and construction material management. Its objectives include extending the useful life of landfills, minimizing the amount of waste, conserving non-renewable resources, increasing the recycling rate, showing the public the true cost of waste management, and 
encouraging the maximum efficient in waste management operations and minimization of related cost.

\section{- P7: Landfill Charging Scheme}

In 1999, a Landfill Charging Scheme was proposed to be adopted based on two principles, namely Polluter Pays Principle and User Pays Principle.

\section{- P8: “Construct for Excellence” report}

In 2001, Construction Industry Review Committee jointed with Buildings Department, Lands Department and Planning Department published a report Construct for Excellence to encourage design and construction of building which maximize the use of recycled/green building materials and reduce construction waste. There was no incentive provided to foster waste reduction by then.

\section{- P9: JPNs issued as incentives}

Joint Practice Note No.1 (JPN1) published in 2001 serves as a prelude to Joint Practice Note No.2 (JPN2) published in 2002 which provides considerable benefit to reduce construction waste. In JPN2, exemption of site coverage and/or gross floor area (GFA) calculation, subjected to certain criteria, was provided to builders using non-structural prefabricated external walls. The exemption to area occupied by projected windows and slab thickness in non-structural prefabricated external walls is in essence providing extra saleable floor area to developers to hence boost the use of prefabricated external walls.

\section{- P10: Amendment for the Waste Disposal Ordinance}

In 2003, Bills Committee was set up under Legislative Council to propose amendment for the Waste Disposal Ordinance in order to provide a statutory basis for the implementation of the construction waste disposal charging scheme, and to strengthen control against illegal waste disposal.

\section{- P11: Recycled materials}

In 2003, the Buildings Department issued a practice note for structural engineers entitled "Use of Recycled Aggregates in Concrete." This technical guideline can be applied to prescribed mix concrete (20P) and designed mix concrete (25D to 35D) to adopt $100 \%$ and $20 \%$ recycled aggregate respectively.

\section{- P12: “Waste Management Plan” and "Pay for Safety and Environment Scheme”}

In 2003, Environment Transport and Works Bureau produced a circular (Ref: 15/2003) on "Waste Management on Construction Sites" that explained the implementation of the government’s “Waste Management Plan” and "Pay for Safety and Environment Scheme” for 
public construction projects.

\section{- P13: Pilot recycling plant}

In 2004, a pilot recycling plant for inert construction waste was set up in Tuen Mun to convert inert wastes into useful materials such as recycled aggregate for road sub-base and drainage bedding layers, as well as for producing asphalt and minor concrete structures. Recycled aggregate is used in public projects commissioned from 2004-2006.

- $\quad$ P14: Trip Ticket System (TTS)

The system was implemented by the Hong Kong government in 1999 and enhanced subsequently in 2004 [27]. It has been anticipated that the number of cases of construction waste being illegally dumped will increase when CWM policies are strengthened. The TTS is introduced to prevent illegal dumping. With the enactment of the TTS, the destinations as well as the transportation route of construction waste generated by a particular construction project can be easily tracked and monitored so that it is difficult for the transporter to dump the waste in an unauthorized area.

\section{- P15: Construction Waste Disposal Charging Scheme}

In 2005, a Construction Waste Disposal Charging Scheme launched to encourage reduction, sorting and recycling construction waste by waste producers. Two off-site sorting facilities namely, Tuen Mun construction waste sorting facility and Tseung Kwan $\mathrm{O}$ construction waste sorting facility, were also implemented with the waste charging scheme.

\section{- P16: Best practice guide}

In 2009, Hong Kong Construction Association issued the Best Practice Guide for Environmental Protection on Construction Sites to serve as a handy reference to frontline management teams in managing certain critical and environment-prone site issues including construction waste management.

- P17: Updated JPNs 1\&2

Buildings Department, Lands Department, and Planning Department updated the JPNs 1\&2 in 2011. At the core of the updates is that an overall cap of 10\% GFA exemptions for a number of features which still qualify for concession is imposed.

\section{A “roadmap” of construction waste management in Hong Kong}

As an overall effect of these policies, a "roadmap” of CWM in Hong Kong can be illustrated in Figure 2. 
$<$ Figure 2>

Based on the "reduce, reuse, and recycle (3R)" principle, the options for waste management listed in preferred order of avoidance, minimization, recycling, treatment, and disposal have been devised and assimilated into the construction processes in Hong Kong. Specifically, in order to manage construction waste, before site operations commence, contractors have to prepare a waste management plan as part of the overall environmental management plan, and set out waste reduction targets and programmes. It is also advised that contractors need to set up a good housekeeping practice and a waste management monitoring and audit programme, throughout the whole construction processes.

If the waste is unavoidably generated on construction sites, arranging on-site sorting and proper waste disposal are advisable to contractors. In Hong Kong, construction waste is often categorized into an inert and non-inert dichotomy, whereby the inert materials, comprising mainly sand, bricks and concrete, are deposited at public filling areas for land reclamation, while the non-inert portion, consisting of materials such as bamboo, plastics, glass, wood, paper, vegetation and other organic materials, is disposed of at landfills as solid waste. The construction waste arisen is usually in the form of a mixture of both inert and non-inert materials. A segregation of the two parts is of paramount importance [28]. Poon et al. found out that contractors were reluctant to carry out on-site waste sorting owing to various difficulties in spite of the perceived advantages to do so [21]. A recent study by Yuan et al. revealed that CWM regulations have significantly enhanced on-site construction waste sorting in Hong Kong [11]. Site space and project stakeholders' attitudes are still regarded as the most critical factors affecting on-site CWM but labour and cost are no longer of major concerns [11]. As a consequence, the waste materials can be reduced, reused, or recycled to a certain degree.

Contractors must send the residual construction waste to different facilities including landfill sites, construction waste off-site sorting facilities, or public fill reception facilities. Based on the "polluter pays principle”, the Hong Kong government implemented a Construction Waste Disposal Charging Scheme (CWDCS) in 2006. In line with the Scheme, a construction contractor will be imposed a levy of HK\$125 for every ton of construction waste it disposes of at landfills; it will be levied HK\$100 per ton if the construction waste was accepted by off- 
site sorting facilities while it will be charged only HK\$27 per ton if the waste consists entirely of inert materials accepted by public fill reception facilities. The EPD has set up rigid criteria to accept different mixture of construction waste. For example, the off-site sorting facilities only accept construction waste containing more than $50 \%$ by weight of inert materials in order to maximize its service efficiency [29].

The price discriminations reflect different environmental impacts caused by different forms of construction waste. For the inert construction waste, it can be sent to public fill reception facilities. The facilities includes: (a) public filling areas, which is a designated part of a development project accepting public fill for reclamation; (b) public filling barging points, which is a strategically located public fill reception facility utilizing barge transportation to transfer public fill from road vehicles to marine based public filling areas; (c) public fill stockpiling areas, a newly reclaimed land where public fill is stockpile as surcharging material to accelerate settlement; (d) fill banks, an area allocated for temporary stockpile of public fill for later use; and (e) construction and demolition material recycling facility, which processes hard inert materials into recycled aggregate and granular materials for use in construction activities. The public fill reception facilities are managed by the CEDD. For the mixed construction waste meeting the criteria, contractors can send it to construction waste sorting facilities as this will be charged less than that disposal of at landfill. There are two operating sorting facilities: (1) Tseung Kwan O Area 137, and (2) Tuen Mun Area 38, for sorting the inert part of construction material from mixed waste (see Figure 3). The inert part will be sent to public fill reception facilities by the CEDD or its off-site waste sorting contractors while the non-inert part will be dumped at landfills. At present, there are three strategic landfills, namely, West New Territories (WENT) Landfill, South East New Territories (SENT) Landfill, and North East New Territories (NENT) Landfill, are in operation (see Figure 4). Yuan et al. noticed that the two off-site construction waste sorting facilities are cleverly sited next to the landfills so that the non-inert waste sorted can be conveniently disposed [11]. Landfill is the least preferred and the most expensive option for waste disposal; it causes environmental problems as well as bringing tremendous pressure to the valuable landfill space.

$<$ Figure 3>

$<$ Figure $4>$ 


\section{Results and Discussions}

\section{Municipal solid waste and construction waste}

Figure 5 illustrates various solid wastes disposed of at landfills in 1991-2010. It is clear that domestic waste and construction waste are the two largest members in forming the overall municipal solid waste in Hong Kong. It can be seen from Figure 5 that the portion of domestic waste remains largely unchanged over the past three decades regardless of the fluctuation in Hong Kong economy. Probably for this reason, the Hong Kong EPD is now shifting its waste management focus to combating the domestic waste, e.g. implementing a plastic bag levy- the 50 cent (US\$0.06) charge for every plastic bag used at grocery counters - since July 2009, and promoting reducing food waste recently. Notably, both the absolute volume and the ratio of construction waste in the overall municipal solid waste have been readily reduced from the highest point (68\% in 1991) to around $25 \%$ over the past years (see years of 2007 to 2010).

$<$ Figure 5 $>$

\section{The influence of a declining construction sector}

Is the reduction of construction waste because of the decreasing construction volume? It is understandable that the more construction projects, the more construction waste may be generated in general. We thus proportioned the construction waste to Gross Domestic Product (GDP). As shown in Table 1, Owing to economic restructuring, the contribution of the construction industry to Hong Kong's GDP dropped from 11\% at its peak in the 1980s but is still consistently contributing around 3\% to the GDP, which was approximate HK\$ 1,748 billion. Figure 6 shows that construction generated around 40 - 70 tonne of waste in producing every million dollars' work during the first half of the last decade while this figure was reduced to around 20 tonne in the recent years ranging from 2008-2011. After eliminating the effects of construction volume variations, encouragingly, there is still a significant drop of construction waste generation in Hong Kong.

<Table 1>

$<$ Figure 6> 


\section{The inert and non-inert dichotomy}

The inert and non-inert dichotomy has greatly helped achieve this reduction. The inert and non-inert dichotomy as a philosophy implies that the inert materials, by temporarily reserved in the public filling facilities, can be used for the future purposes, e.g. land reclamation, thus theoretically their impact is negligible. Figure 7 illustrates the construction waste disposed of at landfills and the inert materials reused or received at pubic filling facilities. Although the overall construction waste generated has increased during 1991 and 2005, the ratio of construction waste disposed of at landfills has been readily reduced. Table 2 and Figure 8 illustrate in greater detail the quantities of construction waste landfilled between 2000 and 2011. Notably, there is a significant increase in quantities of construction waste in 2002. The reason is that several reclamation projects were closed in 2002, earlier than expected. The number of reclamation sites to which inert waste could be sent has been drastically reduced. The construction waste that would originally be used in the reclamation sites had to be transferred to the landfills. This causes the increase of about $59 \%$ or $1,384,810$ tons over 2001 to 2002. This, from another perspective, also explains why the inert and non-inert dichotomy helps significantly reduced the construction waste disposal of at landfills in the period.

$<$ Figure 7>

$<$ Table 2>

$<$ Figure 8>

The Green Manager Scheme, Waste Disposal Regulations and Waste Disposal (Designated Waste Disposal Facility) Regulation

There is a clear reduction of construction waste in 1995 (see Figure 5). It also has a significant drop for the ratio of construction waste disposed of at landfills after 1994 (see Figure 7). This can be explained from the significant implementation of CWM policies after 1994. In particular, the Green Manager Scheme, Waste Disposal Regulations, and Waste Disposal (Designated Waste Disposal Facility) Regulation were implemented in 1994, 1995, and 1996 respectively. The implementations of CWM policies increase awareness by the construction companies in CWM, including waste sorting and the 3R principle. 


\section{The Construction Waste Disposal Charging Scheme (CWDCS)}

The above table and figures also record a significant drop of construction waste in 2005 from all the three landfills, a slightly increase in 2010 and a slightly drop in 2011. Hao et al. also reported that waste has been reduced by approximately $60 \%$ in landfills, by approximately 23\% in public fills, and by approximately 65\% in total waste between 2005 and 2006 [30]. By linking the reduction back to Table 1 and Figure 6, it can be seen that this is a genuine reduction of overall construction waste, which is worth more in-depth interpretations. The clear drop of waste generation in 2005 is the direct benefit from the implementation of the CWDCS at the same year. About $37.09 \%$ or 887,568 tons of waste generation has been reduced in 2006 compared to that in 2005, with a further reduction of about $23.44 \%$ or 353,005 tons of waste generation in 2007 compared to that in 2006.

With the detail analysis by months of the waste generation to landfills (see Figure 9), it always has a significant drop in February but return back in March every year. This is believed due to February being normally the month of Chinese Spring Festival, which is considered as a very important festival for Chinese in Hong Kong. Most of the projects will try to finish before February or start in March.

$<$ Figure 9>

In addition to the waste sent to landfills, waste segregated in the construction off-site waste sorting facilities should also be considered. The CWDCS and the implementation of construction waste off-site sorting facilities were both implemented in 2005. Construction waste has been found significantly reduced after the implementation of the CWDCS, as some of the construction waste can be diverted to the facilities.

Table 3 and Figure 10 show the summary of intake and disposal quantities of construction waste sorting facilities. It is clear that total waste collected to the construction waste sorting facilities was significantly reduced of about $33.76 \%$ or 468,765 tons in 2007 compared to that in 2006 and further reduced of about $48.06 \%$ or 379,373 tons in 2011 compared to that in 2010.

<Table 3> 
$<$ Figure 10>

\section{Lessons learnt}

Generally speaking, the policies of CWM in Hong Kong can be categorized into statutory and non-statutory requirements [31]. Statutory requirements for CWM such as Waste Disposal (Amendment) Ordinance (1997) are compulsory whereby failing to comply means commitment of an offence that is punishable while non-statutory CWM requirement such as the joint practice notes are not part of the legislations or regulations but can improve and promote environment-friendly awareness to the industry. It can be seen from Figure 1 that the years from 1994 to 2005 witness the most intensive promulgation of public policies in responding to the increasing concerns on construction waste in the territory. Amongst the policies such as the Green Manager Scheme, Waste Disposal Regulations, the CWDCS seems having the largest magnitude in terms of reducing construction waste disposal of at landfills. This strengthens the belief that "attempts to significantly reduce waste generation would not be possible in the absence of major economic incentives to drive the requisite behavioral change” [19]. Studies conducted by Yuan et al. and Yu et al. have also reported that the effects of the construction waste disposal charging scheme have been channeled back to construction sites to urge contractors in conducting better waste management such as onsite sorting [11, 32].

Nevertheless, the CWDCS was not introduced overnight without confrontations. Rather, it has gone through a relatively long period before these regulations are accepted by stakeholders such as clients, contractors, and transporters [33]. One can see from Figure 1 that a landfill charging scheme was proposed to be adopted as early as 1999 based on two principles, namely Polluter Pays Principle and User Pays Principle. But the 1999 version was not successful. One of the interviewees reflected that the lorry drivers struck and almost blocked the traffic system in Hong Kong at that time to protest against the Scheme. It was not until 2006 that the CWDCS has been finally implemented. Two lessons can be learnt from Hong Kong's experience in implementing CWM policies: (a) to form an interlocking policy system; and (b) to launch education and campaign of sustainable development in the society.

Hong Kong has developed a delicately interlocking policy system for CWM. For example, in parallel with the CWDCS in 2006, two off-site construction waste sorting facilities were set up in view that some contractors may not have enough space to conduct on site waste sorting. 
Policies such as the Country Parks and Special Areas Regulation (Cap. 208A), the Public Cleansing and Prevention of Nuisance Regulation (Cap. 132BK), and the Dumping at Sea Ordinance (Cap. 466) are in place to prevent that construction waste is illegally dumped in undesignated places. Particularly, a Trip Ticket System (TTS) was introduced in 1999 and enhanced in 2004 to prevent illegal dumping, which is envisaged to increase after the enactment of the construction waste disposal charging scheme, although $\mathrm{Yu}$ et al. reported that it is difficult to obtain concrete proof of illegal dumping [32]. More about the TTS can be seen in Lu and Yuan [33]. Another example is the JPN 1\&2 issued to incentivize the adoption of green features in buildings through GFA exemption. Using prefabrication to reduce construction waste was one of the green features. But in a sense this has been abused so that the JPNs were updated in 2011 to cap the overall GFA exemption. Governments should be allowed enough time to perfect the policy system.

Another lesson learnt is to promote the value of sustainable development (SD) to foster an atmosphere that is conducive to CWM policy implementation. To improve some of the practices and allow more consultations undoubtfully contributed to the successful implementation of the CWDCS in 2006, but a changing socio-economic background toward embracing SD as an underlying contributory factor should not be neglected. During the period, EPD and other government departments have launched various campaigns and schemes to promote SD. As a result, philosophies such as 3R principals, polluters pay principal, and extended producers responsibility principle, have been increasingly accepted by the society. Under such atmosphere, the resistance to CWM policies can be neutralized. This echoes with our interviews, which reflected that in recent years vocational training has been given to construction workers to educate good practices including on-site waste management.

\section{Challenges ahead}

Nevertheless, looking specifically into the period from 2006-2012 after the CWDCS was successfully implemented, CWM maintains a stably low but gloomy situation in Hong Kong. As can be seen from Table 1 and Figure 5, the construction sector, contributing only around 3\% of Hong Kong's GDP, however, sends 11 to 15 million ton of waste to the landfills per annum, taking around 25\% of the overall municipal solid waste disposal of at landfills. Yuan et al. [11] reported that the CWDCS has been channeled back to construction sites to conduct more effective waste management while $\mathrm{Yu}$ et al. [32] further reported that no much CWM 
behavior changes have been observed with subcontractors' and in some trades. Although it has a significant improvement of CWM in Hong Kong after the implementation of CWDCS in 2005, this seems to be a pause of the implementation of CWM policies since that. It is necessary to consider other CWM policies that can further reduce the waste generation. Whether it is possible to further reduce the negative impacts of construction waste either through policy methods or low waste technologies, or taking the view from our interviewees that a certain level of waste generation is unavoidable, is a question challenging the policymakers, practitioners, and researchers in Hong Kong.

\section{Conclusions}

Construction waste apportions a major part of the total municipal solid waste in contributing to the environment degradation in most cities including Hong Kong. Various policies for managing construction waste have been implemented by the Hong Kong government and her executive arms over the past decades. A longitudinal review reveals that Hong Kong is actively trying new construction waste management (CWM) policies based on latest waste management philosophies available (e.g. 3R principle, and polluter pays principle). The policies have formed an interlocking, and relatively effective policy framework for regulating CWM in Hong Kong. Amongst them, the inert and non-inert dichotomy as a CWM philosophy has helped divert the inert construction materials to public filling facilities, and thus significantly relieved the pressure on valuable landfills for accepting non-inert waste. The Construction Waste Disposal Charging Scheme (CWDCS) and its associated measures (e.g. the construction waste off-site sorting facilities) implemented in 2006 have the largest magnitude in terms of genuinely reducing construction waste both onsite and disposal of at landfills. Solid waste generated from producing every million dollars’ construction work has been significantly reduced to 20 tonne in recent years from 40 - 70 tonne during the first half of the last decade. However, CWM remains a gloomy situation in Hong Kong after the CWDCS was successfully implemented in 2006. Contributing only around 3\% to the GDP, the construction sector however disposes of $25 \%$ of the overall municipal solid waste at landfills in Hong Kong. To further reduce the negative impacts of construction waste is a challenge ahead facing the policy-makers, practitioners, researchers, and the like.

\section{Acknowledgements}

The research was supported by the Hong Kong Research Grants Council (RGC) Public 
Policy Research (PPR) Scheme (RGC Ref. HKU7016-PPR-11) and the National Nature Science Foundation of China (NSFC) project (No.: 71273219). Thanks are due to Ms. Julie Kwan, and Mr. Ivan Hui for their assistance in this research.

\section{References}

[1] World Commission on Environment and Development. Our common future. Oxford University Press, United Kingdom, 1987.

[2] Lu W, Yuan HP. A framework of understanding waste management studies in construction. Waste Management 2011;31:1252-1260.

[3] Brown L, Flavin C, Kane H. Vital signs 1996: The trends that are shaping our future. Norton Co and Worldwatch Institute, 1996.

[4] Lenssen N, Roodman DM. Making better buildings in state of the world 1995. Worldwatch Institute, 1995.

[5] Ofori G. The environment: the fourth construction project objective? Construction Management and Economics 1992;10:369-395.

[6] United Nations Centre for Human Settlements. People, settlements, environment and development. United Nations Centre for Human Settlements, 1990.

[7] United Nations Centre for Human Settlements. Development of national capacity for environmental sound construction. United Nations Centre for Human Settlements, Nairobi, 1993.

[8] Worldwatch Institute. State of the world 1995. Norton, 1995.

[9] Boiral O, Henri JF. Modelling the impact of ISO 14001 on environmental performance: A comparative approach. Journal of Environmental Management 2012;99:84-97.

[10] Coelho A, de Brito J. Influence of construction and demolition waste management on the environmental impact of buildings. Waste Management 2012;32:532-541.

[11] Yuan HP, Chini AR, Shen LY. A dynamic model for assessing the effects of management strategies on the reduction of construction and demolition waste. Waste Management 2012;32:521-531.

[12] Comoglio C, Botta S. The use of indicators and the role of environmental management systems for environmental performances improvement: a survey on ISO 14001 certified companies in the automotive sector. Journal of Cleaner Production 2012;20:92-102. 
[13] Ferguson J, Kermode N, Nash CL, Sketch WAJ, Huxford RP. Managing and minimizing construction waste: a practical guide. Institution of Civil Engineers, 1995.

[14] Sealey BJ, Phillips PS, Hill GJ. Waste management issues for the UK ready-mixed concrete industry. Resources, Conservation and Recycling 2001;32:321-331.

[15] Craven EJ, Okraglik HM, Eilenberg IM. Construction waste and a new design methodology. Sustainable Construction: Proceedings. Of the 1st Conference of CIB TG 16, 1994, 89-98.

[16] McDonald B. RECON waste minimisation and environmental program. Proceedings of CIB Commission Meetings and Presentations, Melbourne, Australia, 1996, 14-16.

[17] Rogoff MJ, Williams JF. Approaches to implementing solid waste recycling facilities. Noyes, Park Ridge, NJ, 1994.

[18] Kilpatrick D. Definitions of public policy and law. http://www.musc.edu/vawprevention/policy/definition.shtml, National Violence Against Women Prevention Research Center, Medical University of South Carolina, United States, 2010.

[19] Environmental Protection Department. Hong Kong Environment 2012. Hong Kong Government, 2012.

[20] Poon CS, Yu TW, Ng LH. A guide for managing and minimizing building and demolition waste. The Hong Kong Polytechnic University, 2001.

[21] Poon CS, Yu TW, Ng LH. On-site sorting of construction and demolition waste in Hong Kong. Resources, Conservation and Recycling 2001;32:157-172.

[22] Environmental Protection Department. Hong Kong Environment 2007. Hong Kong Government, 2007.

[23] Tang NS, Zhao YY. Semiparametric Bayesian analysis of nonlinear reproductive dispersion mixed models for longitudinal data. Journal of Multivariate Analysis 2013;115:68-83.

[24] Environmental Protection Department. Monitoring of solid waste in Hong Kong waste statistics for 1999. Environmental Protection Department, Hong Kong Government, 1999.

[25] Chung SS, Poon CS. Quantifying extenalities in solid waste management in Hong Kong. Journal of Environmental Engineering 1997;123:282-289.

[26] Formoso CT, Soibelman L, De Cesare C, Isatto EL. Material waste in building industry: main causes and prevention. Journal of Construction Engineering and Management 2002;128:316-325. 
[27] Hong Kong Discovery Bay. Trip ticket system. Hong Kong Discovery Bay, Hong Kong Special Administration Region, 2010.

[28] Wang JW, Yuan HP, Kang XP, Lu W. Critical success factors for on-site sorting of construction waste: a China study. Resources, Conservation and Recycling 2010;54:931-936.

[29] Environmental Protection Department. Waste reduction framework plan 1998-2007. Hong Kong Government, 2008.

[30] Hao JL, Hills MJ, Tam VWY. The effectiveness of Hong Kong's Construction Waste Disposal Charging Scheme. Waste Management and Research 2008;26:553-558.

[31] Hong Kong Construction Association. Best practice guide for environmental protection on construction sites. Hong Kong Construction Association, 2009.

[32] Yu ATW, Poon CS, Wong A, Yip R, Jaillon L. Impact of construction waste disposal charging scheme on work practices at construction sites in Hong Kong. Waste Management 2012; In Press:

[33] Lu W, Yuan HP. Off-site sorting of construction waste: what can we learn from Hong Kong? Resources, Conservation and Recycling 2012;69:100-108.

[34] Civil Engineering and Development Department. Construction waste sorting facilities. Civil Engineering and Development Department, Hong Kong Special Administrative Region, China, 2012. 
Table 1: GDP and waste contributed by construction (year 2000-2011)

\begin{tabular}{|l|r|r|r|r|r|r|r|r|r|r|r|r|}
\hline Year & 2000 & 2001 & 2002 & 2003 & 2004 & 2005 & 2006 & 2007 & 2008 & 2009 & 2010 & 2011 \\
\hline Construction (M HKD) & 62532 & 57590 & 51850 & 45237 & 40797 & 39010 & 39227 & 40643 & 48403 & 50264 & 56531 & 64527 \\
\hline Contribution to GDP (\%) & 4.9 & 4.5 & 4.1 & 3.7 & 3.2 & 2.8 & 2.7 & 2.5 & 3 & 3.2 & 3.3 & 3.4 \\
\hline Waste (Tonne) & 2728375 & 2338920 & 3723730 & 2455720 & 2407175 & $2,393,305$ & $1,505,737$ & $1,152,732$ & $1,131,527$ & 1139014 & 1308159 & 1215940 \\
\hline Waste/GDP (Tonne/M HK\$) & 43.63 & 40.61 & 71.82 & 54.29 & 59.00 & 61.35 & 38.39 & 28.36 & 23.38 & 22.66 & 23.14 & 18.84 \\
\hline
\end{tabular}

Note: GDP related data were at basic prices. 
Table 2: Quantities of construction waste landfilled in 2000-2011(in tons)

\begin{tabular}{|l|l|l|l|l|}
\hline & SENT & NENT & WENT & Total \\
\hline 2000 & $2,025,020$ & 310,250 & 393,105 & $2,728,375$ \\
\hline 2001 & $1,727,180$ & 306,235 & 305,505 & $2,338,920$ \\
\hline 2002 & $3,041,545$ & 350,400 & 331,785 & $3,723,730$ \\
\hline 2003 & $1,834,855$ & 345,290 & 375,575 & $2,455,720$ \\
\hline 2004 & $1,804,560$ & 323,390 & 279,225 & $2,407,175$ \\
\hline 2005 & $1,806,750$ & 310,980 & 275,575 & $2,393,305$ \\
\hline 2006 & $1,127,599$ & 101,586 & 276,551 & $1,505,737$ \\
\hline 2007 & 864,602 & 110,413 & 177,717 & $1,152,732$ \\
\hline 2008 & 837,856 & 127,666 & 166,005 & $1,131,527$ \\
\hline 2009 & 823,198 & 144,524 & 171,292 & $1,139,014$ \\
\hline 2010 & 942,139 & 156,914 & 209,106 & $1,308,159$ \\
\hline 2011 & 848,561 & 167,055 & 200,324 & $1,215,940$ \\
\hline
\end{tabular}

Note: SENT is South East New Territories Landfill; NENT is North East New Territories Landfill; and WENT is West New Territories Landfill. 
Table 3: Quantities of intake and disposal summary of construction waste off-site sorting facilities (in tons) [34]

\begin{tabular}{|c|c|c|c|c|c|c|c|c|c|}
\hline & \multicolumn{3}{|c|}{ Tuen Mun sorting plant } & \multicolumn{3}{|c|}{ Tseung Kwan O sorting plant } & \multicolumn{3}{|c|}{ Total } \\
\hline & Accepted & To landfill & To fill bank & Accepted & To landfill & To fill bank & Accepted & To landfill & To fill bank \\
\hline 2006 & 399,451 & 199,084 & 189,630 & $1,062,213$ & 760,820 & 239,055 & $1,461,664$ & $69.13 \%$ & $30.87 \%$ \\
\hline 2007 & 176,504 & 101,951 & 73,859 & 716,358 & 575,091 & 168,923 & 892,862 & $73.61 \%$ & $26.39 \%$ \\
\hline 2008 & 152,605 & 92,242 & 62,892 & 610,039 & 508,052 & 98,238 & 762,644 & $78.84 \%$ & $21.16 \%$ \\
\hline 2009 & 176,440 & 90,218 & 82,717 & 572,043 & 519,193 & 69,240 & 748,483 & $80.04 \%$ & $19.96 \%$ \\
\hline 2010 & 155,012 & 107,205 & 56,776 & 608,184 & 573,185 & 52,242 & 763,196 & $86.19 \%$ & $13.81 \%$ \\
\hline 2011 & 138,256 & 78,215 & 59,178 & 283,914 & 159,569 & 113,073 & 422,170 & $57.99 \%$ & $42.01 \%$ \\
\hline 2012 (part) & 17,742 & 11,395 & 9,254 & 40,499 & 22,315 & 21,163 & 58,241 & $52.57 \%$ & $47.43 \%$ \\
\hline
\end{tabular}




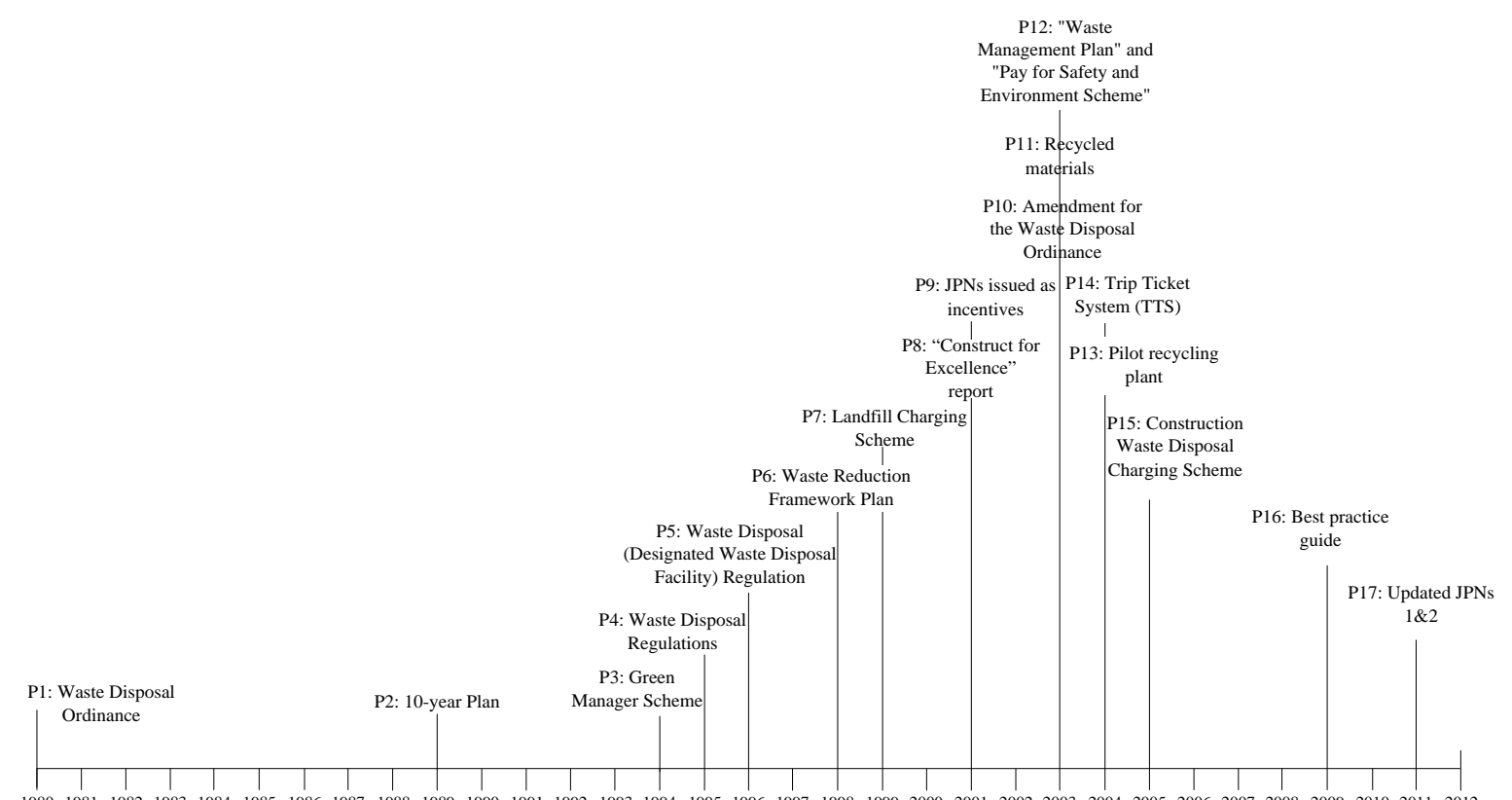

Figure 1: Policy framework of CWM in Hong Kong 


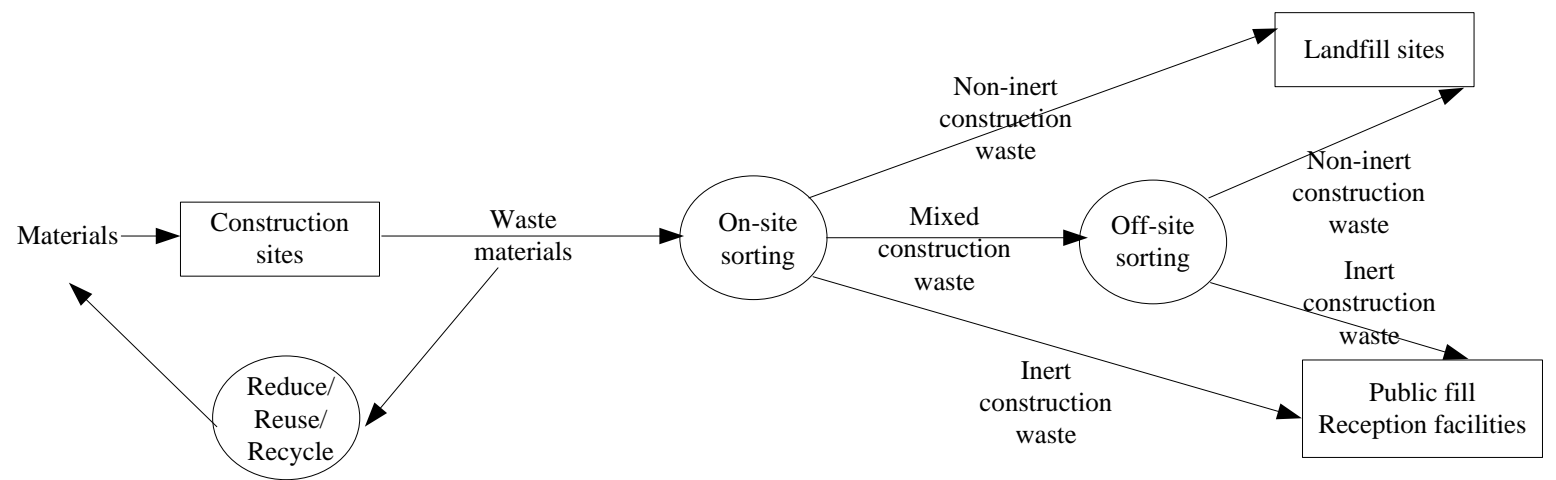

Figure 2: Construction waste generation and management in Hong Kong 


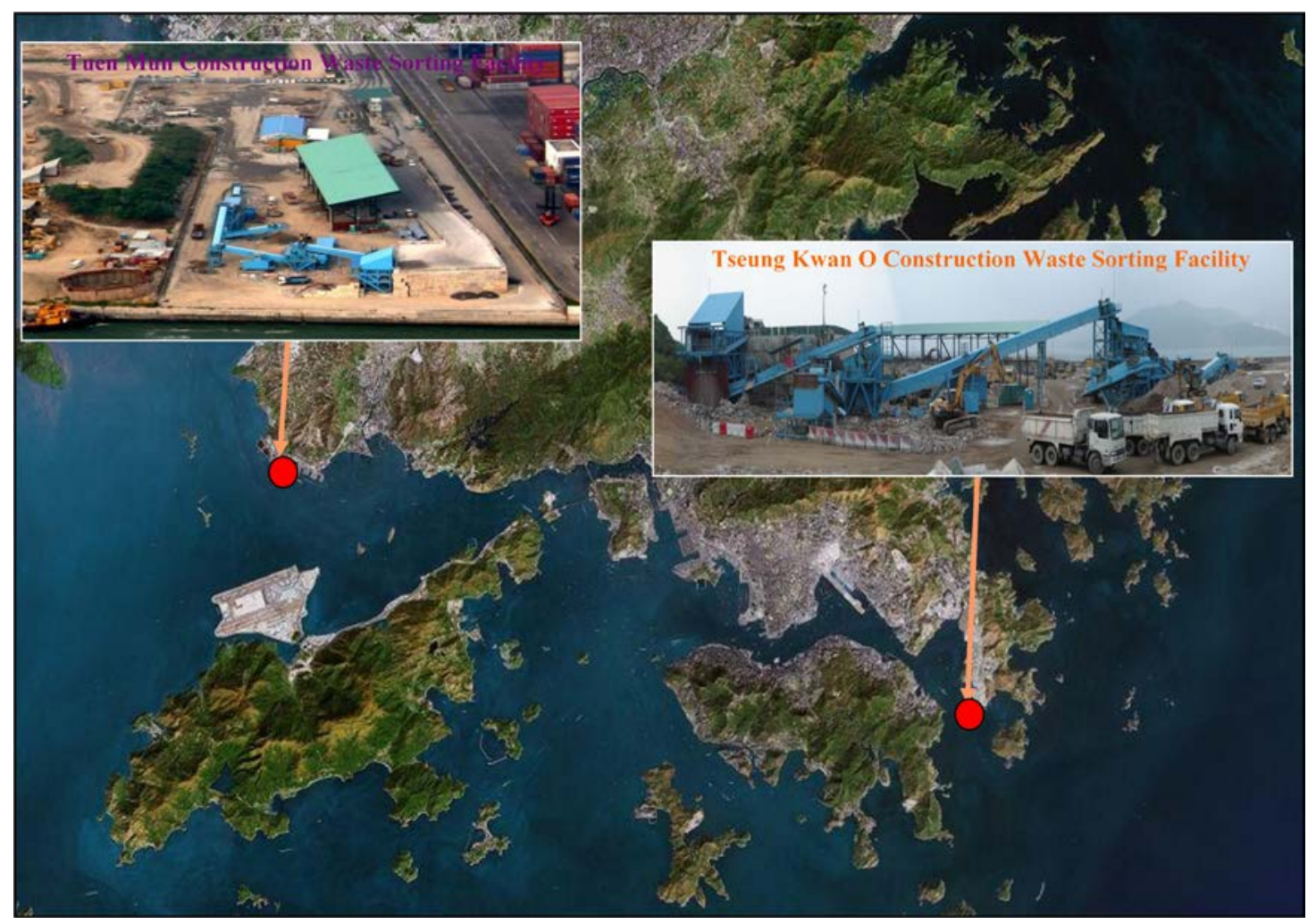

Figure 3: Two construction waste sorting facilities in Hong Kong [34] 


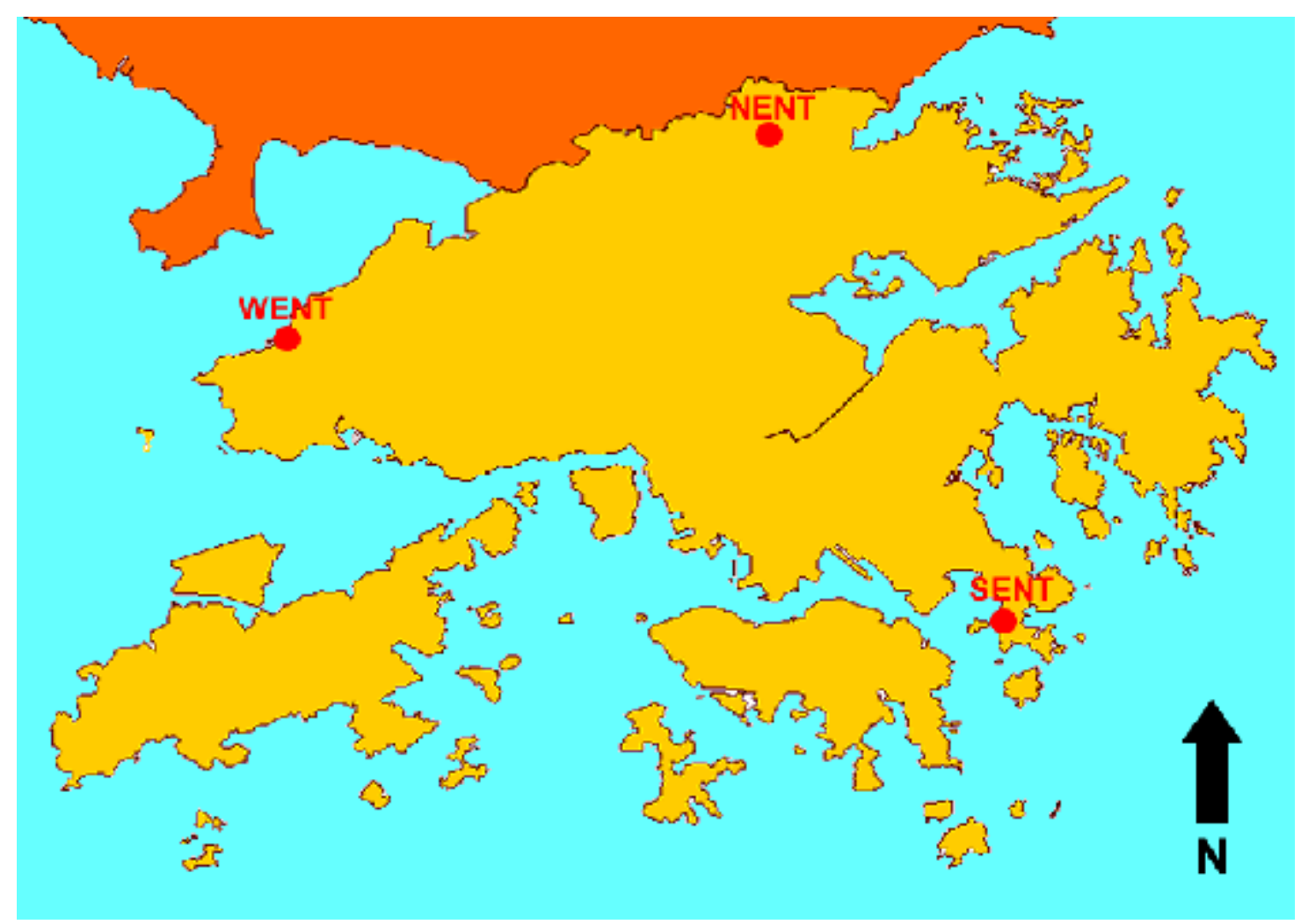

Figure 4: Location of existing strategic landfills in Hong Kong [19] 


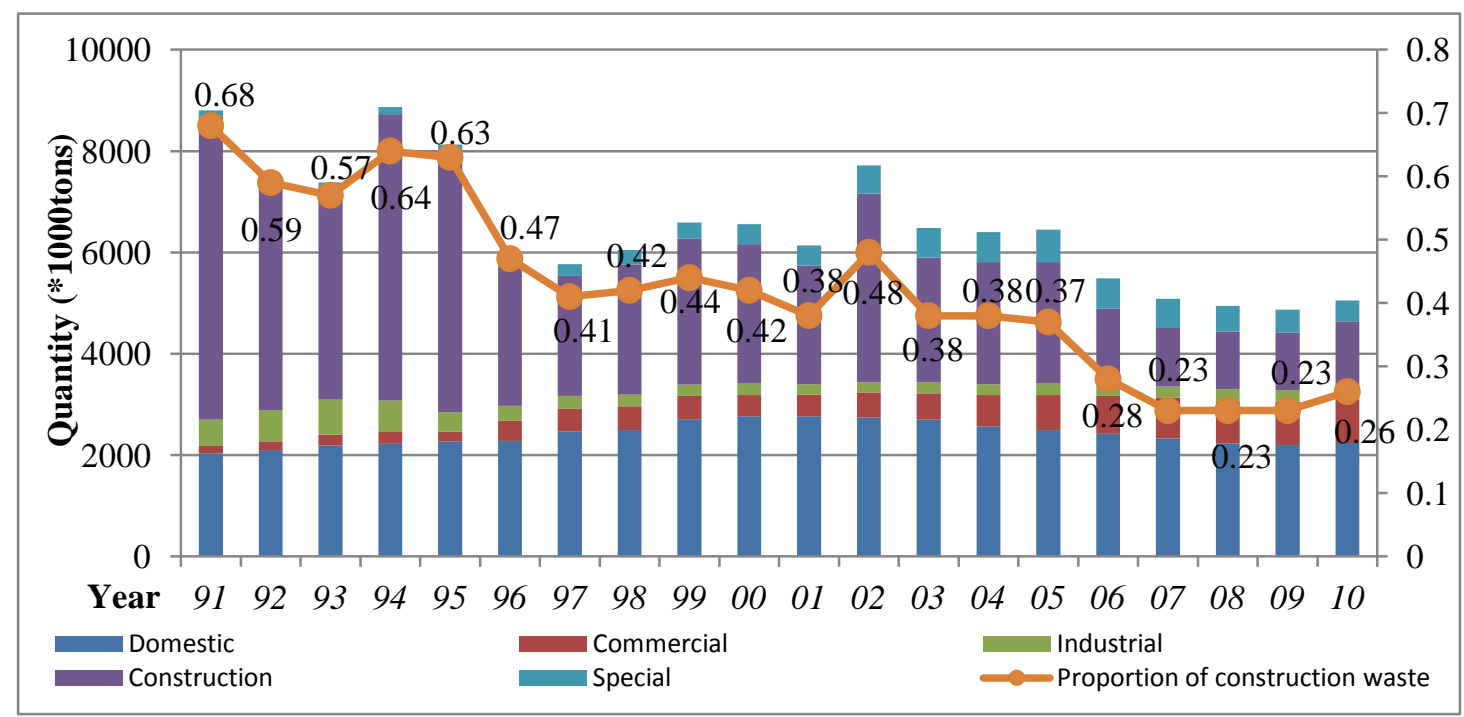

Figure 5: Solid waste disposed of at landfills from 1991 to 2010 [19] 


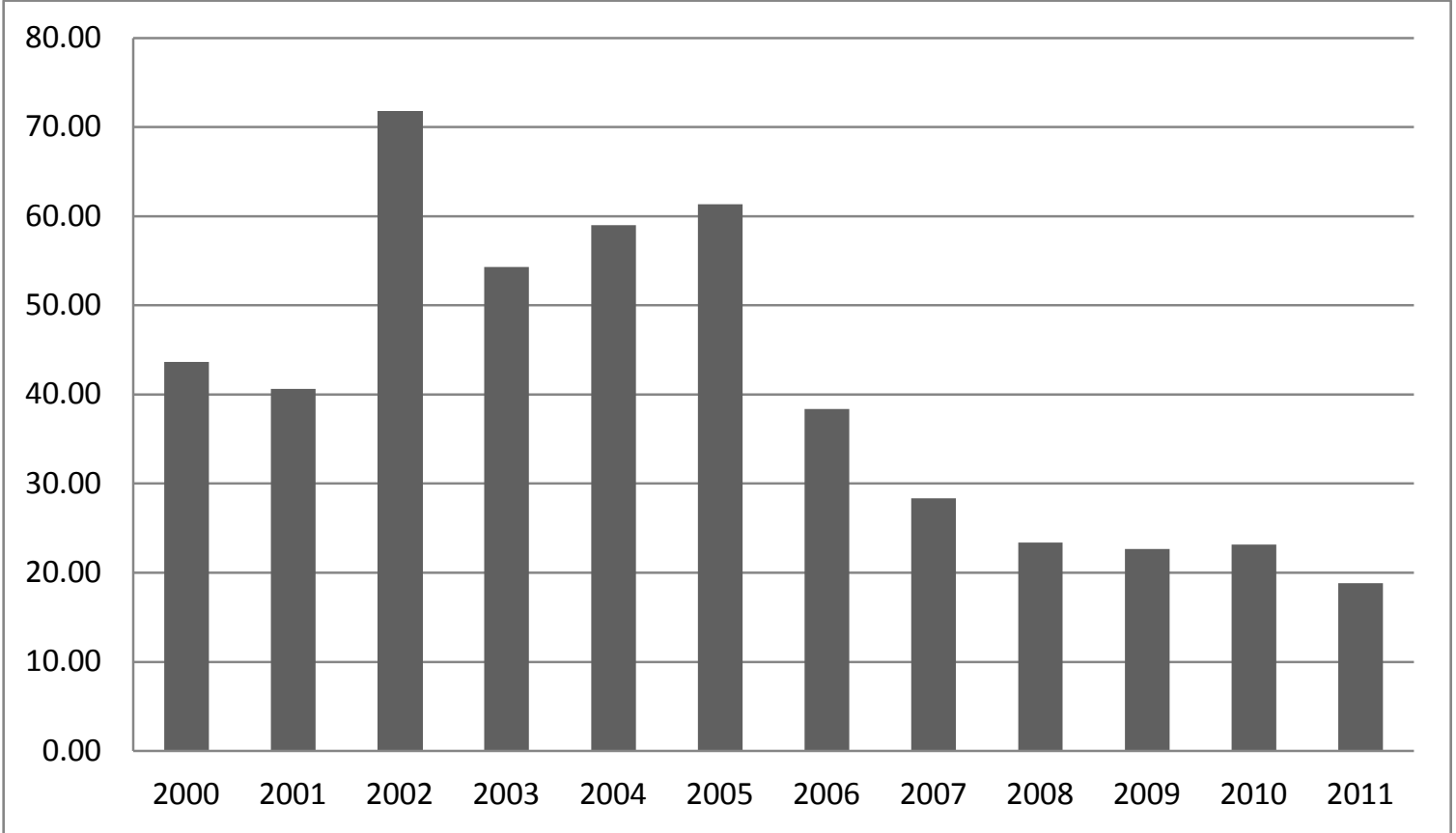

Figure 6: Waste generation per construction GDP in Hong Kong (Unit: ton/M HK\$) 


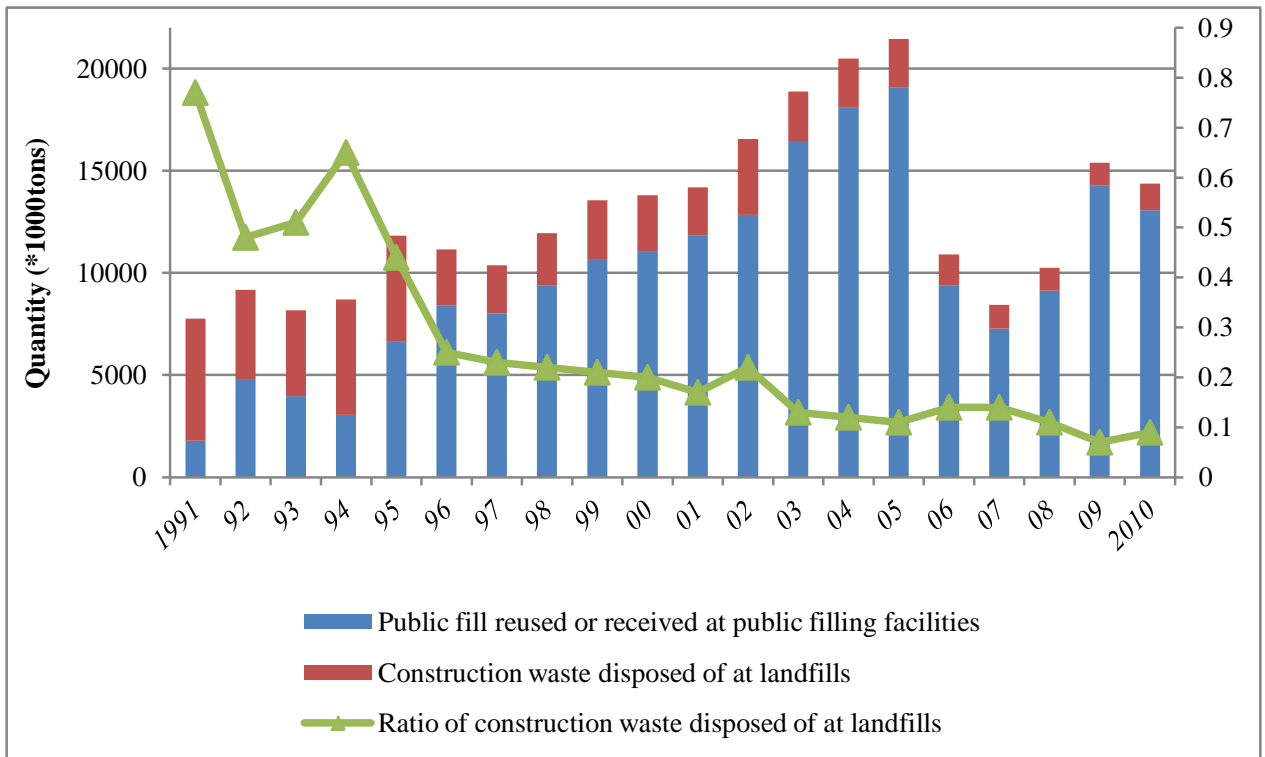

Figure 7: Quantities of construction waste in 1991-2010 [19] 


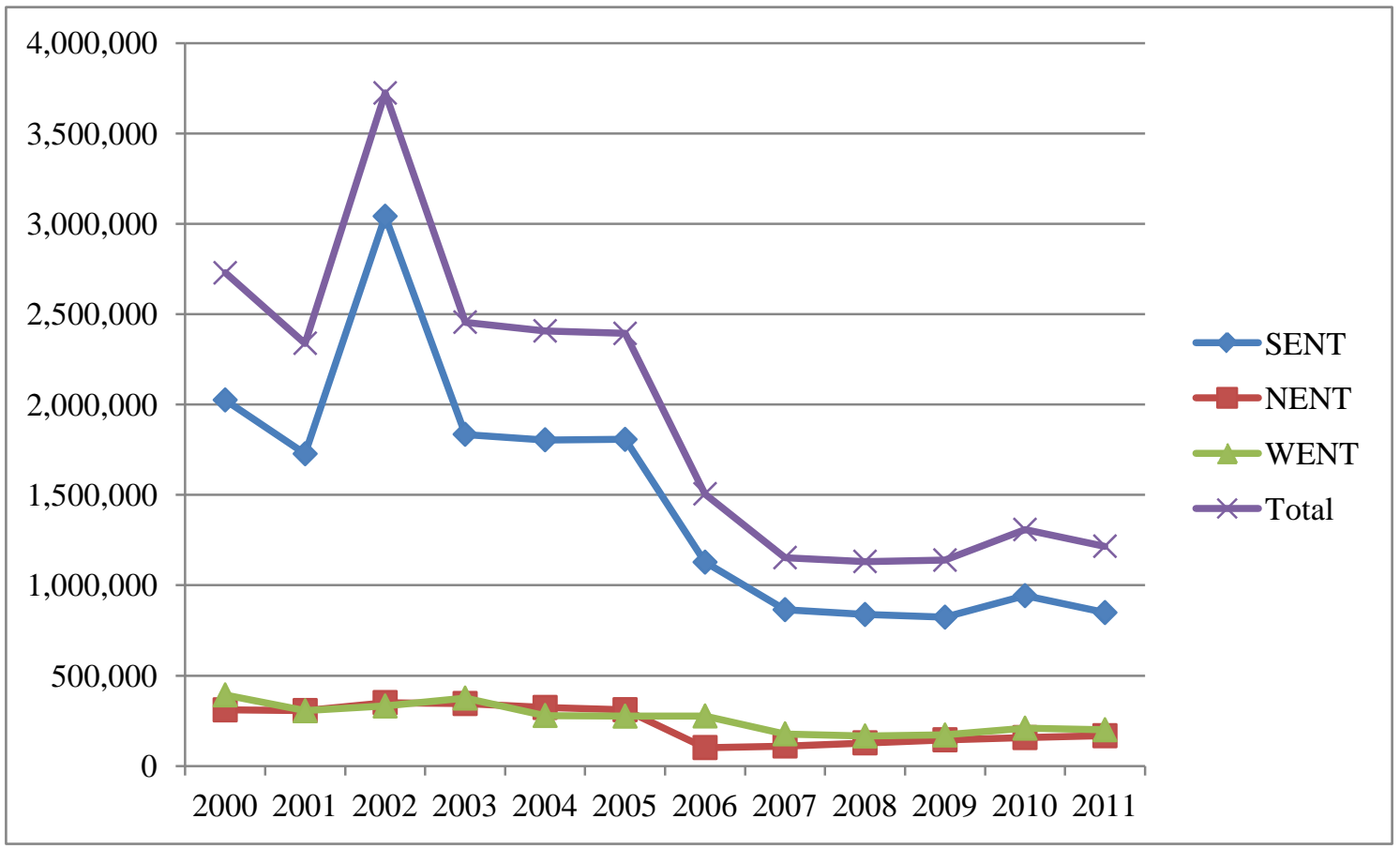

Note: SENT is South East New Territories Landfill; NENT is North East New Territories Landfill; and WENT is West New Territories Landfill.

Figure 8: Quantities of construction waste landfilled in 2000-2011 (in tons) 


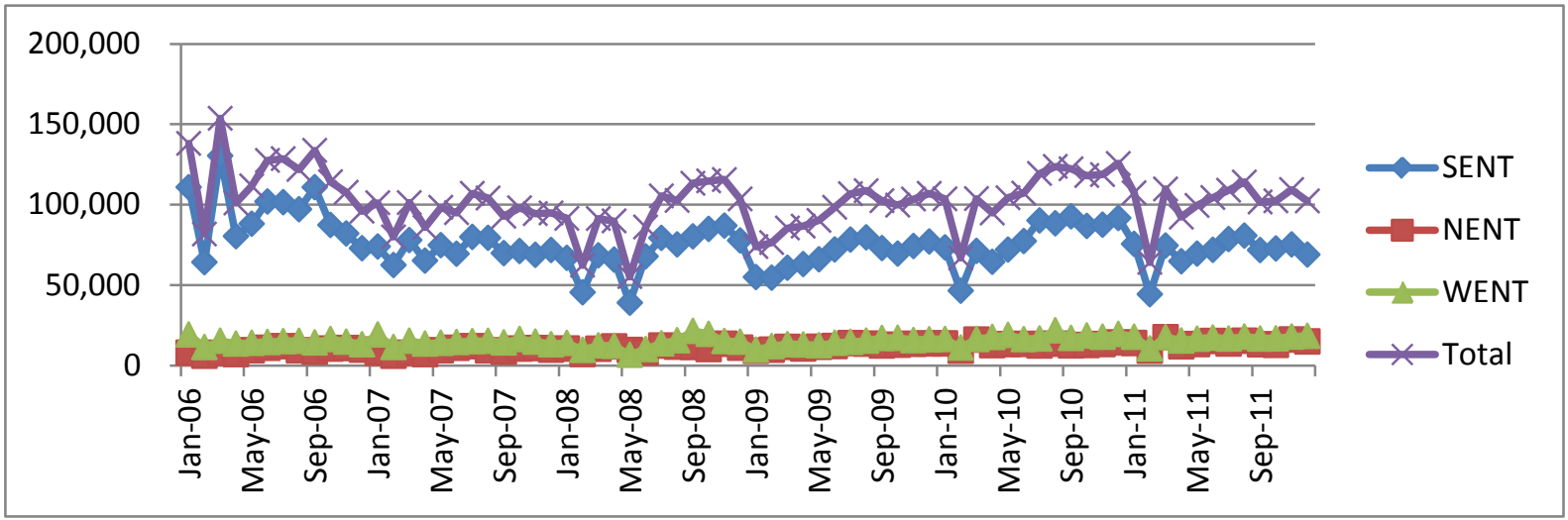

Note: SENT is South East New Territories Landfill; NENT is North East New Territories Landfill; and WENT is West New Territories Landfill.

Figure 9: Quantities of construction waste landfilled in 2006-2011 (by month) 


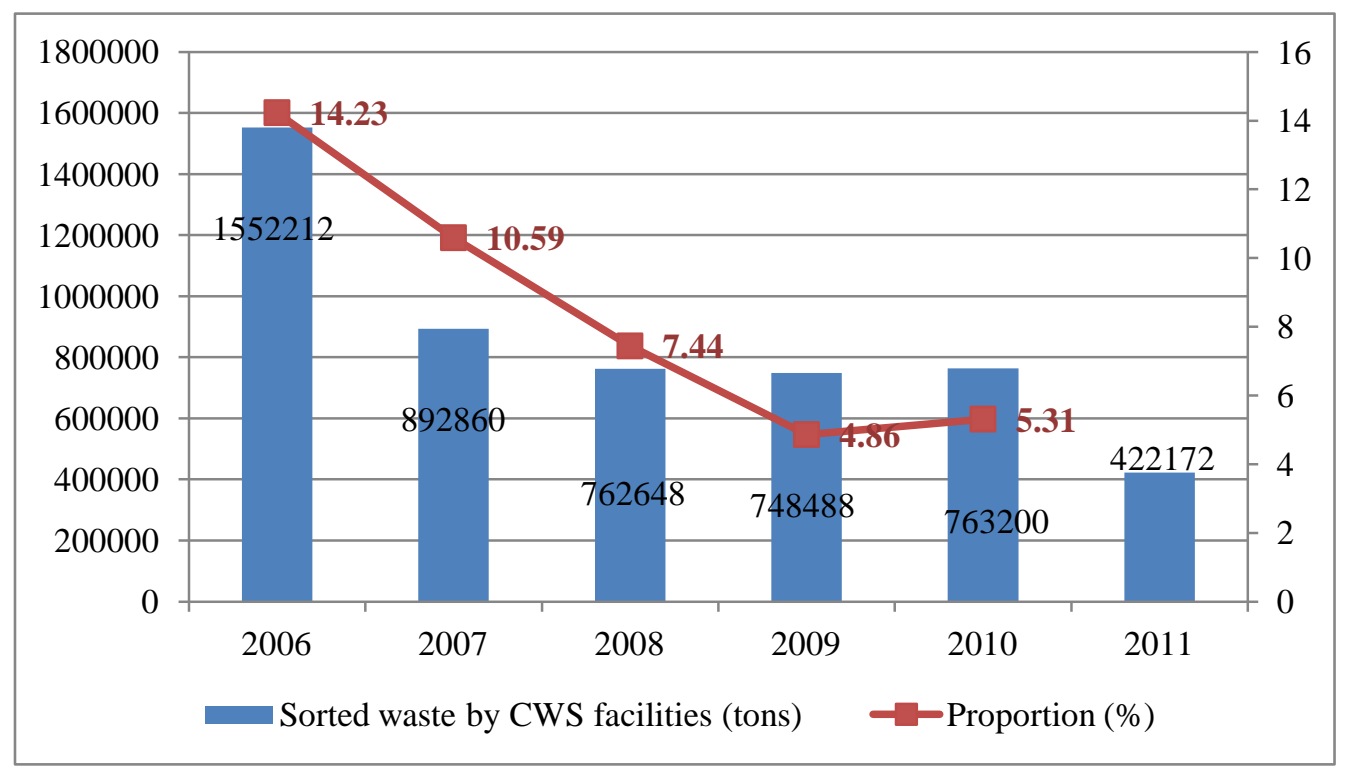

Figure 10: Construction waste sorted by the off-site construction waste sorting facilities [34] 